\title{
KLASIFIKASI KESALAHAN DAN HAMBATAN PENGGUNAAN BAHASA INDONESIA SEBAGAI BAHASA AKADEMIK PADA MAHASISWA FTK UIN MATARAM
}

\author{
Sultan, Dwi Yulianingsih \\ PBA FTK UIN Mataram, SDN Nyurlembang Narmada \\ sultan@uinmataram.ac.id, dwijneng@gmail.com
}

Abstract: This study aims to (1) classify errors in the use of Indonesian language which include the use of spelling and punctuation, word selection, sentence composition, paragraph preparation in the scientific work of FTK UIN Mataram students; (2) describe the obstacles and solutions for the use of Indonesian in writing scientific papers among students of UIN Mataram. This study uses a descriptive qualitative approach that is supported by verbal data writing. Data collection in research uses documentation and interviews. The documentation was taken from the fifth semester students' scientific work of the Arabic Language Education Department. The results showed that the errors in the use of Indonesian language of FTK UIN Mataram students included $35 \%$ letter writing errors, $45 \%$ writing punctuation errors, $25 \%$ word selection errors, and $20 \%$ sentence writing mistakes. The obstacles in the use of Indonesian in the scientific work of students of the Faculty of Engineering UIN Mataram are language barriers and non-language barriers. Language barriers in the form of not mastering Indonesian language rules correctly, and non-linguistic barriers include lack of practice and habituation, control of the results of writing scientific papers for students of the Faculty of Engineering UIN Mataram. The solution that can be done is to get used to the use of Indonesian language based on language rules, coaching by lecturers through mentoring writing scientific papers Key words: errors, and barriers to language use

Abstrak: Penelitian ini bertujuan untuk (1) mengklasifikasikan kesalahan penggunaan bahasa Indonesia yang meliputi pengguanaan ejaan dan tanda baca, pemilihan kata, penyusunan kalimat, penyusunan paragraf dalam karya ilmiah mahasiswa FTK UIN Mataram; (2) mendeskripsikan hambatan dan solusi penggunaan bahasa Indonesia dalam penulisan karya ilmiah di kalangan Mahasiswa FTK UIN Mataram. Penelitian ini menggunakan pendekatan kualitatif deskriptif yang didukung dengan data verbal tulisan. Pengumpulan data dalam penelitian menggunakan dokumentasi dan wawancara. Dokumentasi diambil dari karya ilmiah mahasiswa semester V Jurusan Pendidikan Bahasa Arab. Hasil penelitian menunjukkan bahwa kesalahan penggunaan bahasa Indonesia mahasiswa FTK UIN Mataram 
meliputi kesalahan penulisan huruf $35 \%$, kesalahan penulisan tanda baca $45 \%$, kesalahan dalam pemilihan kata $25 \%$, dan kesalahan dalam penyusunan kalimat $20 \%$. Adapun hambatan dalam penggunaan bahasa Indonesia dalam karya ilmiah mahasiswa FTK UIN Mataram adalah hambatan kebahasaan dan hambatan non-kebahasaan. Hambatan kebahasaan berupa kurang menguasai kaidah bahasa Indonesia dengan benar, dan hambatan nonkebahasaan meliputi kurangnya latihan dan pembiasaan, pengontrolan terhadap hasil menulis karya ilmiah bagi mahasiswa FTK UIN Mataram. Adapun solusi yang dapat dilakukan adalah dengan pembiasaan penggunaan bahasa Indonesia berdasarkan kaidah kebahasaan, pembinaan oleh dosen melalui pendampingan penulisan karya tulis ilmiah.

Kata kunci: Kesalahan, dan hambatan penggunaan bahasa

\section{A. Pendahuluan}

Bahasa Indonesia merupakan bahasa pengantar yang digunakan dalam dunia akademik (perkuliahan), oleh sebab itu bahasa Indonesia menjadi mata kuliah wajib yang harus dikaji oleh mahasiswa di perguruan tinggi. Hal ini berdasarkan amanat UUD 1945 bahwa bahasa Indonesia sebagai bahasa negara, UU N0. 20/2003 dan PP No. 19/2005 menetapkan bahasa Indonesia sebagai mata kuliah wajib di seluruh perguruan tinggi negeri dan swasta dengan bobot 3 SKS. Secara Operasional, SK. Dikti No. 43 Tahun 2006 mengukuhkan bahasa Indonesia sebagai Mata Kuliah Pengembang Keperibadian (MPK).

Sejak penetapannya, bahasa Indonesia sebagai bahan kajian sudah berlangsung cukup lama, namun lamanya waktu dalam mengkaji bahasa Indonesia, tidak seimbang dengan skill/kemampuan berbahasa Indonesia terutama bahasa tulis akademik di kalangan pelajar/mahasiswa. Hal ini juga selaras dengan temuan peneliti yang selalu mengikuti dan mengoreksi hasil karya tulis ilmiah mahasiswa dari tahun ke tahun, dalam penulisan karya ilmiah, seperti makalah dan skripsi, masih banyak terdapat kesalahan bahasa Indonesia dalam mendeskripsikan hasil pemikirannya dengan standar bahasa Indonesia yang baik dan benar.

Orientasi kajian bahasa Indonesia di perguruan tinggi adalah keterampilan menulis ilmiah, yakni tulisan yang logis dan sistematis, kelogisan cara berpikir menjadi identitas dan ruh dari kehadiran perguruan tinggi, di samping itu, perguruan tinggi mempunyai peranan penting dalam mencetak kader-kader penerus bangsa yang mempunyai sumber daya manusia yang potensial. Di antara bentuknya adalah keterampilan berbahasa akademis yang baik dan benar.

Terampil menggunakan bahasa merupakan tujuan terpenting dalam kegiatan berbahasa. Keterampilan berbahasa meliputi, keterampilan menyimak, berbicara, membaca, dan menulis. Di antara keterampilan berbahasa yang diajarkan dalam bahasa Indonesia di perguruan tinggi adalah keterampilan menulis, khususnya tulisan ilmiah, karena menulis ilmiah merupakan proses aktivitas kreatif-akademis 
yang dilakukan oleh mahasiswa, baik saat memenuhi tugas pada tiap-tiap mata kuliah ataupun saat menyelesaikan tugas akhir/skripsi.

Di antara ciri tulisan ilmiah yang berkualitas (dari sudut kebahasaan) adalah tulisan yang menggunakan bahasa Indonesia dengan baik dan benar serta didukung argumentasi logis dan lugas. Bahasa Indonesia yang baik berarti bahasa yang mempunyai nilai rasa yang tepat dan sesuai dengan situasi pemakaiannya, sedangkan bahasa Indonesia yang benar adalah pemakaian bahasa yang menerapkan kaidah dengan konsisten.

Adapun kaidah dalam bahasa Indonesai adalah menyangkut ejaan, pilihan kata/ diksi yang tepat/sesuai, padu dan logis, dan pola penggunaan paragraf yang kohesi dan koherensi. Ejaan merupakan kaidah dalam bahasa Indonesia yang mengatur tentang penulisan huruf, pemakaian tanda baca, pola penomoran, pembentukan kata dan penulisan istilah. Pilihan kata mengatur pola penulisan sanding kata yang tepat dan kata yang padu dan logis. Kemudian paragraf yang (kohesi dan koherensi) artinya paragraf yang berimbang antara bentuk/struktur bahasa dengan gagasa/ide yang disampaikan penulis.

Penggunaan bahasa yang tidak menggunakan kaidah kebahasaan tersebut akan dikategorikan kesalahan. Hal ini selaras dengan klasifikasi Carder (1981) bahwa kesalahan berbahasa terdiri dari tiga klasifikasi, pertama lapses, kesalahan jenis ini adalah kesalahan berbahasa yang disebabkan oleh perubahan cara berbicara komunikan sebelum selesai menyampaikan ungkapannya, kesalahan jenis ini adalah kategori kesalahan atas ketidaksengajaan. Kedua error, kesalahan jenis ini terjadi akbiat pelanggaran aturan kebahasaan oleh komunikan. Ketiga mistake, kesalahan penggunaan bahasa akibat komunikan tidak tepat dalam menggunakan diksi yang sesuai dengan konteks tuturan yang dikemukakan.

Urgensi penelaahan klasifikasi kesalahan dan hambatan penggunaan bahasa Indonesia pada tulisan ilmiah mahasiswa adalah untuk mengkaji dan mengidentifikasi jenis-jenis kesalahan yangjamak terjadi dan hambatan yang dialami dalam penggunaan bahasa Indonesia oleh mahasiswa FTK UIN Mataram.

Kesalahan bentuk/struktur bahasa yang dipergunakan menyebabkan pesan yang disampaikan tidak dapat dipahami dengan benar oleh pembaca, terlebih dalam tulisan ilmiah, karena dalam tulisan ilmiah, setiap redaksi harus menggunakan kata yang bermakna denotatif bukan bermakna konotatif.

Dari paparan di atas, masalah yang akan dibahas dalam penelitian ini adalah klasifikasi kesalahan dan hambatan penggunaan bahasa Indonesia sebagai Bahasa Akademik pada mahasiswa FTK UIN Mataram.

\section{B. Landasan Teori}

Pada bagian ini, penulis memaparkan konsep teori sebagai acuan dalam melakukan analisis sesuai dengan fokus masalah dalam penelitian ini. Tori yang 
dipaparkan dalam penelitian ini adalah konsep kesalahan berbahasa dan korelasi logis bahasa Indonesia dalam karya ilmiah, berikut penulis memaparkan landasan teori tersebut.

\section{Konsep Kesalahan Berbahasa}

Istilah kesalahan berbahasa memiliki pengertian yang beragam, untuk itu, pengertian kesalahan berbahasa perlu dipaparkan dengan terperinci. Kesalahan berbahas menurut Carder (1974) bahwa ada tiga istilah untuk menamai kesalahan berbahasa, pertama disebut Lapser, kedua Error, dan ketiga disebut Mistake. Sementara bagi Bunt dan Kiparsky (1984), ia mengistilahkan kesalahan berbahasa itu dengan istilah goof dan goofing. Sedangkan Hudan (1981) mengistilahkan dengan istilah kekhilafan. Adapun Tarigan (1997) menyebutnya dengan istilah kesalahan berbahasa, dan Sultan (2013) menyebutnya dengan istilah keliru.

Beberapa istilah yang berbeda tentang istilah dalam kesalahn berbahasa memiliki titik kesamaan dan memiliki titik perbedaan. Namun pada perinsipnya kesamaan terfokus pada ketidaksesuaian dalam penggunaan bahasa terhadap kaidah kebahasaan, baik bahasa lisan maupun bahasa tulisan.

Untuk lebih fokus, berikut penulis akan memaparkan beberapa istilah dalam kesalahan berbahasa, seperti Lapsess, Error, dan Mistake. Ketiga istilah ini memiliki domain yang berbeda-beda dalam memandang kesalahan berbahasa.

\section{a. Lapsess}

Lapsess adalah kesalahan berbahasa akibat penutur beralih cara untuk menyatakan sesuatu sebelum seluruh tuturan (kalimat) selesai dinyatakan selengkapnya. Dalam bahasa lisan, kesalahan jenis ini diistilahkan dengan "slip of the tongue" sedangkan dalam bahasa tulis diistilahkan "slip of the pen" kesalahan ini akibat ketidaksengajaan dan tidak disadari oleh penuturnya.

b. Errror

Error adalah kesalahan berbahasa akibat penutur melanggar kaidah atau aturan berbahasa. Kesalahan ini terjadi karena penutur sudah memiliki aturan (kaidah) tata bahasa yang berbeda dari tata bahasa yang lain, sehingga berdampak pada kekurangsempurnaan atau ketidakmampuan penutur.

c. Mistake

Mistake adalah kesalahan berbahasa akibat penutur tidak tepat memilih kata atau ungkapan untuk suatu sistem tertentu. Kesalahan ini mengacu kepada kesalahan akibat penutur tidak tepat menggunakan kaidah yang diketahui benar, bukan karena kurangnya penguasaan bahasa kedua (B2). Kesalahan terjadi pada produk tuturan yang tidak benar.

Adapun Burt dan Kiparsky tidak membedakan kesalahan berbahasa, tetapi dia menyebut "goof" untuk kesalahan berbahasa, yakni kalimat-kalimat atau tuturan 
yang mengandung kesalahan, "goofiction" untuk menyebut jenis kesalahan dari kegramatikalan atau tata bahasa. Sedangkan "goofing" adalah penyebutan terhadap seluruh kesalahan tersebut goof dan gooficion.

Sementara menurut Huda (1984) menyebutnya dengan khilaf. Kekhilafan berbahasa adalah suatu hal yang wajar dan selalu dialami oleh penutur bahasa dalam peroses pemerolehan bahasa kedua. Hal itu merupakan implikasi logis dari proses kreatifitas.

Adapun Tarigan (1997) menjelaskan bahwa ada dua istilah yang bersinonim (memiliki makna yang kurang lebih sama), kesalahan (Error) dan kekeliruan (Mistake) dalam pengajaran bahasa kedua. Kesalahan berbahasa adalah penggunaan bahasa yang menyimpang dari kaidah bahasa yang berlaku dalam bahasa itu, namun tidak dipandang sebagai suatu pelanggaran berbahasa. Kekeliruan ini terjadi pada pembelajar bahasa. Kekeliruan berbahasa cenderung diabaikan dalam analisis kesalahan berbahasa, karena sifatnya tidak acak, individual, tidak sistematis, dan tidak permanen. Jadi, analisis kesalahan berbahasa difokuskan pada kesalahan berbahasa berdasarkan penyimpangan kaidah bahasa yang berlaku dalam bahasa itu. Dalam riset ini juga, penulis menganalisis kesalahan berbahasa yang menyimpag dari kaidah bahasa Indonesia yang baik dan benar.

Beberapa referensi juga yang berguna bagi landasan berpijak untuk penelitian ini antara lain: Norish (1983) tentang pembelajar bahasa dan kesalahan-kesalahannya, termasuk di dalamnya kesalahan pembelajar dalam menulis; H.V. George (1972) mengenai kesalahan-kesalahan umum yang dilakukan oleh pembelajar, beberapa penyebab kesalahan berbahasa, dan cara mengatasi kesalahan berbahasa. Grady (1989) juga mengemukakan tentang kesalahan berbahasa yang dihubungankan dengan masalah interlanguage dan interference dalam perolehan bahasa kedua.

Tarigan (1988) memaparkan mengenai teori kesalahan berbahasa dan langkah-langkah dalam melakukan analisis kesalahan berbahas, ia membahas secara rinci pengajaran remedi bahasa sebagai tindak lanjut ditemukannya berbagai kesalahan berbahasa agar kesalahan-kesalahan tersebut tidak terjadi lagi dalam proses pembelajaran bahasa asing/kedua.

Norish (1983: 6-8) memandang perlunya membedakan tiga tipe penyimpangan berbahasa yang berbeda. Tiga hal itu meliputi error, mistake, dan lapse. Error(kesalahan) merupakan penyimpangan berbahasa secara sistematis dan terus-menerus sebagai akibat belum dikuasainya kaidah-kaidah atau norma-norma bahasa target. Mistake (kekeliruan) terjadi ketika seorang pembelajar tidak secara konsisten melakukan penyimpanagn dalam berbahasa. Kadang-kadang pembelajar dapat mempergunakan kaidah yang benar tetapi kadang-kadang mereka membuat kekeliruan dengan mempergunakan kaidah dan bentuk-bentuk yang keliru. Lapse, (selip lidah) diartikan sebagai bentuk penyimpangan yang diakibatkan karena pembelajar kurang konsentrasi, rendahnya daya ingat atau sebab-sebab lain yang dapat terjadi kapan saja dan pada siapa pun. 
Selain membedakan berbagai bentuk penyimpangan berbahasa, Norish juga menyatakan bahwa kesalahan-kesalahan berbahasa pembelajar dapat dijadikan alat bantu yang positif dalam pembelajaran karena dapat dipergunkan oleh pembelajar maupun pengajar dalam mencapai tujuan pembelajaran bahasa.(Norish, 1983: 6).

Berkaitan dengan kesalahan dalam menulis, Norish berpendapat bahwa penting untuk mendorong pembelajar dapat menyusun kalimat-kalimat mereka secara tertulis sehingga kesalahan-kesalahan yang dibuat hendaknya direduksi bahkan dihilangkan sama sekali.(Norrish, 1983: 65). Untuk itu, Norish mengajukan beberapa alternatif koreksi kesalahan dalam menulis antara lain, (1) memeriksa pekerjaan dalam kelompok atau secara berpasangan, (2) melakukan aktivitas dengan keahlian terpadu, (3) mempergunakan kode-kode koreksi untuk menandai pembetulan atas kesalahan-kesalahan yang dibuat pembelajar.

George (1972: 2) berpendapat bahwa kesalahan adalah sebuah bentuk yang tidak diinginkan, khususnya, bentuk yang tidak diinginkan oleh para perancang kursus dan para guru. Hal ini berkaitan erat dengan adanya standar-standar tertentu yang telah digariskan oleh penyusun kurikulum. Penyimpangan atas standar-standar tersebut berarti melakukan kesalahan dan harus segera diantisipasi dan diatasi. Sebagai langkah antisipasi, ia mengajukan dua alternatif, (1) memberi waktu khusus untuk melakukan koreksi atas kesalahan-kesalahan, (2) mengarahkan sikap dan perasaan pembelajar pada bentuk-bentuk standar bahasa target.

Sementara itu Grady menghubungkan 'errors analysis' dengan 'contrastive analysis' dengan asumsi bahwa kesalahan-kesalahan berbahasa yang diproduksi oleh pembelajar akan terjadi pada titik-titik di mana dua bahasa tidak ada kemiripannya...' it was claimed that the error produced by the learner would occur at those points at which the two languages were dissimilar'. Dengan pembandingan dua bahasa, masalah-masalah potensial (kesalahan-kesalahan) dapat diprediksi dan difokuskan dalam pembelajaran bahasa target (O’Grady, 1989:).

Mengenai klasifikasi kesalahan berbahasa, ia mengklasifikan kesalahan menurut sistem gramatikal yang meliputi: fonologi, sintaksis, morfologi, dan semantik, dan klasifikasi kesalahan karena adanya penghilangan, penambahan, dan penggantian bentuk-bentuk tertentu.

Senada dengan O'Grady, dalam Tarigan menyatakan bahwa kesalahan berbahasa sering dijumpai dalam pembelajaran bahasa, baik pembelajaran bahasa kedua atau juga dalam pembelajaran bahasa pertama. Untuk itu, diperlukan suatu prosedur untuk mengurangi atau bahkan menghilangkan sama sekali kesalahan-kesalahan tersebut.

Tarigan mengajukan langkah-langkah prosedur tersebut yang merupakan modifikasi langkah-langkah analisis kesalahan yang diajukan Ellis (1986) dan Sidhar (1985). Langkah-langkah tersebut meliputi: (1) mengumpulkan data yang berupa kesalahan-kesalahan berbahasa yang dibuat pembelajar. (2) mengidentifikasi dan mengklasifikasi kesalahan; tahap pengenalan dan pemilah-milahan kesalahan 
berdasarkan kategori ketatabahasaan. (3) membuat peringkat kesalahan yang berarti membuat urutan kesalahan berdasarkan keseringan kesalahan-kesalahan itu muncul. (4) menjelaskan kesalahan dengan mendeskripsikan letak kesalahan, sebab-sebabnya dan pemberian contoh yang benar. (5) membuat perkiraan daerah atau butir kebahasaan yang rawan menyebabkan kesalahan. (6) mengoreksi kesalahan berupa pembetulan dan penghilangan kesalahan berupa penyusunan bahan yang tepat dan penentuan strategi pembelajaran yang serasi (Tarigan, 1988: 71-72).

Langkah-langkah di atas tidaklah terlalu jauh berbeda dengan langkah-langkah yang diajukan oleh George sebagaimana telah diuraikan di depan. Langkah-langkah inilah yang akan diikuti / dipakai dalam penelitian ini.

Selain langkah-langkah yang diajukan di atas, Tarigan juga mengajukan tahap-tahap pembelajaran remedi sebagai tindak lanjut dari identifikasi dan analisis kesalahan-kesalahan berbahasa. Tahap-tahap itu meliputi, diagnosis kesalahan, perawatan/penyembuhan kesalahan, penanggulangan kesalahan dan perbaikan kesalahan. Pembelajaran remedi ini hendaknya didasarkan atas pertimbanganpertimbangan (1) frekuensi kesalahan, (2) kesalahan insidental atau kesalahan abadi/ terus-menerus, (3) dampak kesalahan tersebut terhadap performansi berbahasa pembelajar, (4) dampak kesalahan tersebut terhadap pemaknaan bahasa, (5) peluang keberhasilan dalam pengurangan kesalahan, (6) dampak pada pembelajar itu sendiri (Tarigan, 1988: 50-56).

\section{Korelasi logis bahasa Indonesia dalam karya ilmiah}

Dalam kegiatan ilmiah, penggunaan bahasa Indonesia dituntut untuk menggunakan bahasa Indonesia yang memiliki ciri keilmuan yang baik dan yang benar. Bahasa yang baik artinya, bahasa yang disesuaikan dengan sifat keilmuan dan situasi pemakaiannya, yakni bahasa tersebut harus tepat, logis, cermat, dan sistematis. Sementara bahasa yang benar artinya, penggunaan bahasa yang sesuai dengan kaidah-kaidah bahasa Indonesia baku, baik ditinjau dari segi ejaan (dalam ragam tulis), fonologi (untuk ragam lisan), morfologi, pilihan kata, sintaksis maupun semantis.

Kegiatan ilmiah dikategorikan kegiatan resmi, oleh sebab itu, ragam bahasa yang digunakan dalam kegiatan ini adalah ragam baku. Setiap ragam bahasa memunyai ciri khas, demikian pula halnya dengan ragam bahasa ilmiah. Dari pengertian tersebut dapat diuraikan ciri-ciri ragam bahasa ilmiah meliputi: (1) Kaidah bahasa Indonesia yang digunakan harus sesuai dengan kaidah bahasa Indonesia baku, baik tata ejaan maupun tata bahasa. (2) Ide yang digunakan harus benar, sesuai dengan fakta atau dapat diterima akal sehat (logis). (3) Ide yang digunakan harus tepat dan hanya mengandung satu makna. Hal ini tergantung pada ketepatan memilih kata dan penyusunan struktur kalimat. (4) Kata yang dipilih harus bersifat denotatif yaitu makna yang sebenarnya. (5) Ide yang diungkapkan dalam kalimat harus padat isi. Oleh sebab itu penggunaan kata dalam kalimat seperlunya, tetapi pemilihannya tepat. (6) Ide dalam kalimat ataupun alenia diungkapkan secara runtun dan sistematis. (7) 
Ide yang diungkapkan dalam kalimat harus jelas sehingga tidak menimbilkan salah tafsir. (Nazar dalam Agustinus, 2012:3).

\section{Metode Penelitian}

Metode penelitian adalah cara-cara yang dapat digunakan oleh peneliti untuk mengumpulkan data (Arikunto, 2005:100). Merujuk pada masalah dalam penelitian ini, maka metode yang digunakan dalam penelitian ini adalah metode kualitatif deskriptif dengan menggunakan pendekatan linguistik struktural. Adapun ciri penelitian kualitatif adalah berlatar alamiah, bersifat deskriptif, dan analisis secara individual yang berlandaskan kelogisan dan berlatar ilmiah.

Menurut Loflan (dalam Moleong, 2010:157) sumber data utama dalam kualitatif adalah kata-kata dan tindakan, selebihnya adalah tambahan seperti dokumen dan lain-lain. Data dalam penelitian ini mencakup tiga hal, (1) sumber data (2) teknik pengambilan data; (3) teknik analisis data. Sumber data dalam penelitian ini adalah hasil wawancara dan karya ilmiah berupa makalah yang ditulis oleh mahasiswa FTK UIN Mataram. Teknik pengambilan data menggunakan teknik pencatatan dan klasifikasi. Hal ini seperti disebut (Sudaryanto 1993) dengan metode simak dan teknik catat. Adapun teknik analisis data dalam penelitian ini menggunakan teknik analisis kesalahan berbahasa. Teknik analisis data dilakukan melalui: (1) Analisis penggunaan ejaan, tanda baca, pemilihan kata, penyusunan kalimat, dan paragraf. (2) Penarikan simpulan dari hasil penelitian sehingga diperolehklasifikasi dan hambatan penggunaan bahasa Indonesia sebagai bahasa ilmiah pada mahasiswa FTK UIN Mataram.

\section{Pembahasan}

Pada bagian ini, peneliti akan memaparkan temuan dan hasil analisis klasifikasi kesalahan dan hambatan penggunaan bahasa Indonesia sebagai bahasa ilmiah pada mahasiswa FTK UIN Mataram.

\section{Klasifikasi kesalahan penulisan huruf dan penggunaan tanda baca}

Dari 20 karya ilmiah mahasiswa yang dijadikan data dalam penelitian ini, peneliti menemukan kesalahan penulisan huruf dan penggunaan tanda baca sebagaimana terdapat pada tabel berikut.

Tabel 1

Kesalahan penulisan huruf dan tanda baca

\begin{tabular}{c|c|c|c}
\hline \multirow{2}{*}{ No } & \multicolumn{2}{|c|}{ Kesalahan Ejaan Bahasa Indonesia } & \multirow{2}{*}{ Kategori } \\
\cline { 2 - 4 } Data & Penulisan Huruf & Penggunaan Tanda Baca & \\
\hline D1 & 15 & 10 & Error \\
\hline D2 & 20 & 13 & Error \\
\hline D3 & 27 & 15 & Error \\
\hline D4 & 30 & 17 & Error \\
\hline D5 & 17 & 24 & Error \\
\hline D6 & 13 & 18 & Error \\
\hline
\end{tabular}


El-Tsaqafah: Jurnal Jurusan PBA, Vol. 19, No.1, 2020

\begin{tabular}{c|c|c|c}
\hline D7 & 18 & 10 & Error \\
\hline D8 & 20 & 17 & Error \\
\hline D9 & 23 & 16 & Error \\
\hline D10 & 30 & 14 & Error \\
\hline D11 & 23 & 13 & Error \\
\hline D12 & 27 & 18 & Error \\
\hline D13 & 14 & 13 & Error \\
\hline D14 & 18 & 10 & Error \\
\hline D15 & 18 & 16 & Error \\
\hline D16 & 19 & 15 & Error \\
\hline D17 & 10 & 9 & Error \\
\hline D18 & 18 & 19 & Error \\
\hline D19 & 23 & 10 & Error \\
\hline D20 & 19 & 14 & Error \\
\hline Jumlah & 402 & 291 & \\
\hline
\end{tabular}

Dari tabel 1 di atas dapat diketahui klasifikasi kesalahan dalam penulisan huruf dan penggunaan tanda baca. Dari 20 karya ilmiah yang menjadi sumber data, peneliti mendapatkan 402 kesalahan penulisan huruf, dan 291 kesalahan penggunaan tanda baca. Kesalahan penulisan huruf meliputi kesalahan penulisan huruf kapital dan kesalahan penggunaan tanda baca. berikut.

Kesalahan penggunaan huruf kapital tersebut disebabkan oleh beberapa hal

1. tidak dipakainya huruf kapital sebagai huruf pertama pada penulisan judul karangan, seperti terdapat pada data berikut.

Peran media elektronik dalam pembelajaran bahasa arab

Adapun penulisan Judul yang benar dengan menggunakan huruf kapital pada masing-masing kata kecuali kata tugas, seperti judul berikut.

Peran Media Elektronik dalam Pembelajaran Bahasa Arab

2. Tidak dipakainya huruf kapital pada penulisan awal kalimat, seperti kalimat berikut.

konsep agama adalah sebagai acuan ajaran bagi pengautnya.

Kalimat di atas diklasifikasikan salah karena tidak menggunakan huruf pada awal kalimat. Penulisan yang benar adalah

Peran media elektronik dalam pembelajaran bahasa arab.

3. tidak dipakainya huruf kapital pada nama hari, geografi, dan singkatan. Hal ini terdapat pada data berikut.

\begin{tabular}{c|c}
\hline Nama hari, geografi dan singkatan & Penulisan yang benar \\
\hline Selasa & Selasa \\
\hline jawa barat & Jawa Barat \\
\hline Mpd & M.Pd \\
\hline
\end{tabular}


Sementara itu, kesalahan penggunaan tanda baca dalam penelitian ini ditemukan sejumlah kesalahan dari beberapa aspek, yaitu:

1. Kesalahan penggunaan tanda titik.

Kesalahan penggunaan tanda titik disebabkan oleh: pertama penggunaan tanda titik yang seharusnya dipakai di akhir kalimat deklaratif, kedua penggunaan tanda titik pada akhir kalimat yang bukan kalimat deklaratif. Hal ini seperti terdapat pada data berikut.

Dalam konsep agama, apakah nilai-nilai Islam sudah dapat diimplementasikan dengan baik dalam kehidupan sehari-hari.

Kalimat ini salah karena seharusnya kalimat pertanyaan akan diakhiri dengan tanda tanya, namun pada kalimat di atas diakhiri dengan tanda titik. Kalimat ini menjadi benar apabial ditulis dengan redaksi berikut.

Dalam konsep agama, apakah nilai-nilai islam sudah dapat diimplementasikan dengan baik dalam kehidupan sehari-hari?

2. Kesalahan penggunaan tanda koma

Penyabab kesalahan pemakaian tanda koma di antaranya: (a) tanda koma dipakai untuk memisahkan kalimat setara yang satu dari kalimat setara berikut yang didahului oleh kata tetapi dan melainkan. (b) penggunaan tanda koma yang seharusnya tidak perlu digunakan. Seperti pada kalimat berikut, efek getaranya, dapat menghancurkan bangunan dan menimbulkan korban jiwa. Seharunya kalimat ini ditulis tanpa menggunakan tanda koma pada bagian yang tidak diperlukan. Kaliamat di atas menjadi benar jika ditulis efek getaranya dapat menghancurkan bangunan dan menimbulkan korban jiwa.

3. Kesalahan pengguna tanda hubung

Penyebab kesalahan tanda hubung yang ada antara lain: (a) tanda hubung tidak digunakan pada unsur kata yang terputus karena pergantian baris. (b) penggunaan tanda hubung yang tidak tepat atau tidak seharusnya karena bukan merupakan awalan melainkan kata depan.

Kesalahan penggunaan tanda tanya. Penyebab kesalahan penggunaan tanda tanya sebagai berikut: (a) tidak dipakai tanda tanya pada akhir kalimat tanya. (b) penggunaan tanda tanya yang kurang tepat atau tidak seharusnya, karena kalimat tersebut bukan kalimat tanya.

Kesalahan penggunaan tanda seru. Penyebab kesalahan penggunaan tanda seru yaitu, tanda seru seharusnya digunakan sesudah ungkapan atau pernyataan berupa serua atau perintah, atau yang menggambarkan kesungguhan, ketidak percayaan, atau rasa emosi yang kuat. 


\section{Klasifikasi kesalahan pembentukan dan pemilihan kata dalam karya ilmiah mahasiswa FTK UIN Mataram}

Berdasarkan analisis pilihan kata dalam penelitian ini ditemukan kesalahan dalam pilihan kata yang terdiri atas dua unsur, yaitu: (1) pilihan kata, dan (2) penulisan kata.

\section{a. Pembentukan Kata}

Berdasarkan analisis pembentukan kata dalam penelitian ini ditemukan kesalahan dalam penulisan bentuk kata yang terdiri dari tiga aspek utama, yaitu: (1) kata dasar, (2) kata depan, (3) kata serapan. Jenis dan contoh kesalahan pebantukan kata dalam penggunaan bahasa Indonesia oleh mahasiswa FTK UIN Mataram terdapat pada tabel berikut.

\section{Tabel 2}

\section{Klasifikasi kesalahan pembentukan kata}

\begin{tabular}{|c|c|c|}
\hline Jenis kesalahan & Contoh (salah) & Contoh (benar) \\
\hline $\begin{array}{l}\text { Pemenggalan awalan } \\
\text { me- }\end{array}$ & $\begin{array}{l}\text { Amerika serikat luncurkan } \\
\text { pesawat bolak-balik } \\
\text { Columbia. }\end{array}$ & $\begin{array}{l}\text { Amerika serikat meluncur- } \\
\text { kan pesawat bolak-balik } \\
\text { Columbia. }\end{array}$ \\
\hline $\begin{array}{l}\text { Pemenggalan awalan } \\
\text { ber- }\end{array}$ & Samapai jumpa lagi & Sampai berjumpa lagi \\
\hline Peluluhan bunyi / c/ & $\begin{array}{l}\text { Menyermati penjelasan di } \\
\text { atas }\end{array}$ & $\begin{array}{l}\text { Mencermati penjelasan di } \\
\text { atas }\end{array}$ \\
\hline $\begin{array}{l}\text { Bunyi /s/, /k/, / p/, dan } \\
\text { /t// yang tidak luluh }\end{array}$ & $\begin{array}{l}\text { Semua warga Indonesia } \\
\text { harus mentaati aturan dan } \\
\text { perundang-undangan. }\end{array}$ & $\begin{array}{l}\text { Semua warga Indonesia } \\
\text { harus menaati aturan dan } \\
\text { perundang-undangan. }\end{array}$ \\
\hline $\begin{array}{lll}\text { Awalan Ke- yang } \\
\text { keliruguna }\end{array}$ & $\begin{array}{l}\text { Pengendara motor itu } \\
\text { meninggal ketabrak truk }\end{array}$ & $\begin{array}{l}\text { Pengendara motor itu } \\
\text { meninggal tertabrak truk }\end{array}$ \\
\hline $\begin{array}{l}\text { Pemakaian kata akhiran } \\
\text {-ir }\end{array}$ & $\begin{array}{l}\text { Pemerintah desa } \\
\text { mengkoordinir kegiatan } \\
\text { masyarakat }\end{array}$ & $\begin{array}{l}\text { Pemerintah desa mengk- } \\
\text { oordinasi kegiatan masya- } \\
\text { rakat }\end{array}$ \\
\hline
\end{tabular}

Dari data pada tabel 2 di atas dapat dipahami bahwa (1) Penanggalan awalan me- dapat dilakukan hanya pada judul teks bahasa jurnalistik, namun pada tulisan ilmiah penulisan menggunakan awalan yang lengkap. (2) penggalan awalan ber-, kata-kata yang berawalan ber- sering mengandalkan awalan ber. Padahalawalan ber harus dieksplisitkan secara jelas. (3) peluluhan bunyi / c/ kata yang berawalan huruf / c/ harus luluh jika mendapatkan awalan me-. (4) Bunyi /s/, /k/, /p/, dan /t// yang tidak luluh. Kata dasar yang awalnya $s, k, p$, atau $t$ sering tidak luluh jika mendapat awalan me- atau pe-. Padahal menurut kaidah buku bunyi-bunyi itu harus lebur menjadibunyi sengau. (5) Awalan Ke- yang keliruguna. kata-kata yang seharusnya berawalan ter seringdiberi awalan ke. Hal itu disebabkan oleh kekurang cermatan dalam memilih awalanyang tepat. (6) Pemakaian kata akhiran -ir. Pemakaian kata akhiran -ir sangat produktif dalam 
penggunaan bahasa Indonesia sehari-hari. Padahal dalam bahasa Indonesia baku untuk akhiran -ir adalah asi atau isasi.

b. Pilihan Kata

Dalam penelitian ini terdapat tiga aspek utama kesalahan pilihan kata dalam penggunaan bahasa Indonesia, yaitu: (1) kebenaran pilihan kata, (2) kejelasan pilihan kata, (3) keefisienan pilihan kata. Ketiga hal ini terangkum dalam tabel berikut ini.

Tabel 3

\begin{tabular}{c|l|l}
\multicolumn{2}{|c}{ Kesalahan pilihan kata dalam penggunaan bahasa Indonesia } \\
\hline No & \multicolumn{1}{|c}{ Jenis kesalahan } & \multicolumn{1}{c}{ Contoh kesalahan } \\
\hline 1 & Kesalahan pemilihan kata depan & Di malam hari \\
\hline 2 & Kesalahan penggunaan kata ulang & $\begin{array}{l}\text { Semua mahasiswa-mahasiswa melakukan } \\
\text { kajian secara rutin. }\end{array}$ \\
\hline 4 & Kesalahan penggunaan konjungsi & $\begin{array}{l}\text { Kampus dimana lokasi yang dijadikan } \\
\text { tempat kajian akademik oleh maha- } \\
\text { siswa. }\end{array}$ \\
\hline
\end{tabular}

Dari tabel di atas dapat dipahami bahwa: (1) kesalahan pemilihan kata depan terdapat pada kata di, dalam kaidah bahasa Indonesia, jika yang dimaksud adalah katarangan waktu maka yang digunakan sebagai kata depannya adala kata pada, jadi ungkapan yang benar adalah pada malam hari. (2) kesalahan penggunaan kata tidak hemat. Dalam kaidah bahasa Indonesia dijelaskan bahwa penggunaan kata dalam kalimat harus memperhatikan kefektifan dengan tidak menggunakan kata yang memiliki kesamaan makna, seperta kata semua yang berarti jamak tidak boleh diikuti dengan pengulangan kata. Oleh karena itu pemilihan kata yang tepat dalam kalimat ini adalah Semua mahasiswa melakukan kajian secara rutin (3) Kesalahan penggunaan konjungsi. Konjungsi adalah kata yang berfungsi untuk menghubungkan kata dengan kata, kalimat dengan kalimat. Dalam penggunaan konjungsi yang tepat harus dieprhatikan aspek kesesuaian pemilihan konjungsinya.

\section{Klasifikasi kesalahan penyusunan kalimat dalam karya ilmiah mahasiswa FTK UIN Mataram}

Berdasarkan analisis kesalahan dalam penyusunan kalimat ditemukan kesalahan yang terdiri dari tiga aspek yang dibahas, yaitu: (1) kebenaran kalimat (2) kejelasan kalimat (3) kejelasan kalimat.

Penyebab kesalahan dalam penyusunan kalimat adalah: (1) adanya kalimat yang tidak mempunyai kelengkapan struktur, sehingga informasi yang disampaikan tidak lengkap, (2) adanya kalimat yang tidak benbahasa ar strukturnya karena kesalahan penyusunan beberapa unsur dalam kalimat tersebut, (3) adanya kalimat yang penyusunanya kurang memperhatikan pilihan kata dan informasi yang disampaikan tidak diatur secara logis sehingga terdapat pengertian yang salah, dan (4) adanya kalimat yang tidak benar strukturnya karena kesalahan pemilihan unsur untuk menyusun suatu kalimat. 
Penyebab kesalahan pada kejelasan penusunan kalimat adalah: (1) kalimat yang disusun lebih dari satu makna sehingga menimbulkan pemahaman yang tidak jelas bagi pembaca, (2) kesalahan karena penggabungan kalimat yang memepunyai dua ide / lebih yang seharusnya disajikan dalam dua kalimat,dan (3) kesalahan penempatan kalimat sebagai pendukung.

Penyebab kesalahan keefisienan penyusunan kalimat adalah: (1) penggunaan kalimat yang sama dan panjang dengan mengulang-ulang kalimat yang tidak perlu dan menggunakan unsur yang sama, (2) pemakaian kata tugas dan keterangan yang sama, dan (3) kalimat yang digunakan terlalu panjang yang semestinya diakhiri dengan titik masih dilanjutkan sehingga menjadi tidak efisien dan sulit dipahami.

\section{Hambatan Penggunaan Bahasa Indonesia dalam Penulisan Karya Ilmiah di kalangan Mahasiswa FTK UIN Mataram dan Solusi Pembelajarannya}

Dari hasil wawancara yang dilakukan oleh peneliti, peneliti dapat mengklasifikasikan hambatan penggunaan bahasa Indonesia. Secara garis besar hambatan diklasifikasikan menjadi dua, yakni hambatan kebahasaan dan hambatan non-kebahasaan. Kedua hambatan ini akan diuraikan pada bagian berikut. .

\section{a. Hambatan Kebahasaan}

Hambatan kebahasan merupakan problematika yang alami oleh pengguna bahasa yang disebabkan oleh lemahnya penguasaan terhadap kaidah atau aturan kebahasaan, kurangnya perbendahaaran kata, dan kaidah bahasa Indonesia yang sering mengecoh antara kelaziman dalam ungkapan sehari-hari dengan aturan pemakaian yang benar, seperti kata imbauan dan himbauan. Hal ini terungkap dari data hasil wawancara berikut.

Kurangnya perbendaharaan kata, mungkin karena kurang membaca juga. Tapi tergantung topik apa yang ingin di tulis. Karena biasanya punya ide mau nulis apa tapi tidak tau cara mengekspresikan melalui tulisan. Suka bingung mau mulai dari mana. Saat belajar tata bahasanya. Meski bahasa sendiri, kadang memiliki kesulitan saat mengerjakan soal bahasa Indonesia. Karena jujur, sering mengecoh. Dan susah dipahami maknanya.

Dari data di atas juga dapat dipahami bahwa, kesalahan dalam penggunaan bahasa Indonesia disebabkan oleh belum optimalnya proses peningkatan budaya literasi di kalangan mahasiswa.

\section{b. Hambatan non-kebahasaan}

Hambatan non-kebahasaan adalah hambatan eksternal-lingual yang dialami oleh pengguna bahasa. Hal ini terjadi disebabkan oleh motivasi lemah dan kurang pembiasaan dalam penggunaan bahasa Indonesia register akademik. Dari hasil wawancara peneliti dengan informan, ia mengaku jarang berlatih menulis menggunakan bahasa Indonesia yang benar,selain dalam mata kuliah bahasa Indonesia yang mengharuskan meraka untuk menulis karya ilmiah. Oleh karena itu, 
wajar jika masih ditemukan banyak kesalahan berbahasa dalam karangan meraka yang meliputi semua komponen berbahasaan.

Pembelajaran dan pelatihan merupakan dua kegiatan yang berkesinambungan yang terfokus pada aktivitas mahasiswa untuk mendapatkan suatu keterampilan tertentu yang dalam hal ini adalah keterampilan menulis. Hal ini relevan dengan pendapat Suhardi (2005) bahwa dalam pembelajaran masih terkandung upaya penguasaan kognisi untuk melandasi kemampuan selanjutnya, sedangkan dalam pelatihan aspek kognisi harus telah dimiliki oleh mahasiswa yang akan diaplikasikan dalam kegiatan untuk medapatkan keterampilan tersebut. Dengan kata lain, dalam pembelajaran terdapat kegiatan untuk menguasai pengetahuan dan teori-teorinya, sementara dalam pelatihan terkandung konsep membiasakan perilaku tertentu untuk memperoleh keterampilan yang diinginkan. Kurangnya latihan adalah akibat rendahnya motivasi dan kesadaran mahasiswa dalam belajar dan menggunakan bahasa Indonesia. Adapun solusi yang dapat dilakukan adalah dengan pembiasaan penggunaan bahasa Indonesia berdasarkan kaidah kebahasaan, pembinaan oleh dosen melalui pendampingan penulisan karya tulis ilmiah.

\section{E. Penutup}

Berdasarkan temuan dan hasil analisis data yang disajikan dalam bagian sebelumnya dapat diperoleh simpulan bahwa kesalahan penggunaan bahasa Indonesia mahasiswa FTK UIN Mataram meliputi kesalahan penulisan huruf 35\%, kesalahan penulisan tanda baca $45 \%$, kesalahan dalam pemilihan kata $25 \%$, dan kesalahan dalam penyusunan kalimat $20 \%$. Adapun hambatan dalam penggunaan bahasa Indonesia dalam karya ilmiah mahasiswa FTK UIN Mataram adalah hambatan kebahasaan dan hambatan non-kebahasaan.

Hambatan kebahasaan berupa kurang menguasai kaidah bahasa Indonesia dengan benar, dan hambatan non-kebahasaan meliputi kurangnya latihan dan pembiasaan, pengontrolan terhadap hasil menulis karya ilmiah bagi mahasiswa FTK UIN Mataram. Adapun solusi yang dapat dilakukan adalah dengan pembiasaan penggunaan bahasa Indonesia berdasarkan kaidah kebahasaan, pembinaan oleh dosen melalui pendampingan penulisan karya tulis ilmiah. 
El-Tsaqafah: Jurnal Jurusan PBA, Vol. 19, No.1, 2020

Daftar Pustaka

Bayu Dwi Nurwicaksono. 2018. ANALISIS KESALAHAN BERBAHASA INDONESIA PADA TEKS ILMIAH MAHASISWA.AKSIS Jurnal Pendidikan Bahasa dan Sastra Indonesia Volume 2 Nomor 2,

Brooks, A. (2004). Posfeminisme \& Cultural Studies: Sebuah pengantar paling komprehensif (S. Kunto Adi Wibowo, penerjemah dan Idi Subandy Ibrahim, editor). Yogyakarta: Jalasutra. (Karya asli diterbitkan pada 1997).

Darmawan, A. (2006). Seratus buku sastra terpilih karya perempuan. Dalam A. Kurnia (ed.), Ensklopedia sastra dunia (hlm. 224-227).

Ibrahim, A. Gufron. (2008). «Bahasa Terancam Punah: Sebab-sebab Gejala dan Strategi Pemecahannya». Dalam Kongres Internasional lX Bahasa Indonesia. Jakarta: Pusat Pembinaan dan Pengembangan Bahasa

Ika Wahyu Prasetya. 2013. Analisi Kesalahan Berbahasa Tuturan Mahasiswa dalam Seminar Proposal Skripsi Mahasiswa. Pancaran. Vol. 2. No. 2. Halman 11.

Kridalaksana, Harimurti. 2007. Pembentukan Kata dalam Bahasa Indonesia. Jakarta: Gramedia

Kridalaksana, Harimurti. (2008). Kamus Linguistik. Jakarta: Gramedia.

Krisna, F.N. (2014). Studi kasus layanan pendidikan nonformal suku Baduy. Jurnal Pendidikan dan Kebudayaan, 20(1): 1-13

Lumintaintang, Y.B. (2014). Industri film nasional sebagai media pelestarian bahasa ibu dalam upaya memperkuat identitas bangsa: Fenomena penggunaan alih kode. Kumpulan Makalah. Menyelamatkan Bahasa Ibu, Seminar Internasional Hari Bahasa Ibu 2014, 117-125.

Mastoyo, Tri. 2007. Pengantar Metode Penelitian Bahasa. Yogyakarta: Carasvati Book

Prihartono, Wawan. (2012). "Ciri Akustik Tuturan Modus Deklaratif Bahasa Jawa Penutur di Medan(Perbandingan dengan Ciri Akustik Tuturan Modus Deklaratif Bahasa Jawa Penutur di Solo)”. Medan: Tesis USU.

Putrayasa, Ida Bagus. 2009. Tatat Kalimat Bahasa Indonesia. Bandung: Refika Aditama

Ramlan. 2008. Kalimat, Konjungsi,dan Preposisi Bahasa Indonesia dalam Penulisan Karangan Ilmiah. Yogyakarta. Sanata Darma Press

Ratna, N.K. (2011). Antropologi sastra: Peranan unsur-unsur kebudayaan dalam proses kreatif. Yogyakarta: Pustaka Pelajar.

Subroto, Edi. 2007. Pengantar Metode Penelitian Linguistik Struktural. Surakarta: UNS Press

Samsuri. 1991. Analisis Bahasa: Memahami Bahasa Secara Ilmiah. Jakarta: Erlangga

Sultan. 2013. Klirumologi Bahasa Indonesia. Pontianak: STAIN Press 
Soedjito. Djoko Saryono. 2012. Tata Kalimat Bahasa Indonesia. Malang: Aditiya Media

Sunda Ariana. 2012. Kesalahan Penggunaan EYD dalam Karya Ilmiah Dosen Universitas Bina Darma.

Sayuti, S. A. (2008). Bahasa, identitas, dan kearifan lokal dalam perspektif pendidikan. Dalam Mulyana (ed.), Bahasa dan sastra daerah dalam kerangka budaya (hlm. 2344). Yogyakarta: Tiara Wacana.

Sudaryanto. (2015). Metode dan Aneka Teknik Analisis Bahasa. Yogyakarta: Sanata Dharma University Press.

Sundawati Tisnasari. 2017. ANALISIS KESALAHAN BAHASA PADA BANGUN D A $N$ PERPADUAN LEKSEM BAHASA INDONESIA. Jurnal Handayani (JH). Vol 7 (1) Juni 2017, hlm. 28-37

Tarigan. 1997. Analisi Bahasa. Jakarta:Gramedia

Wiradnyana, Ketut. (2011). Pra Sejarah Sumatra Bagian Utara: Kontribusinya pada Kebudayaan Kini. Jakarta: Yayasan Obor Indonesia. 